\title{
IVANA DOBRIVOJEVIĆ
}

Institute of Contemporary History

Belgrade

dobrivojevicivana@ikomline.net

\section{LIVING UNDER DICTATORSHIP. OPPRESSIVE PRACTICES IN YUGOSLAVIA*}

\begin{abstract}
This paper examines the state repression during the dictatorship of king Aleksandar (1929-1935) and early socialism (1945-1953). Special attention is paid to the repressive legislation, political persecutions, violation of political and civil rights and excessive brutality of police forces. This paper is based on primary sources in the Archive of Yugoslavia and Archive of Serbia and select periodicals of the period.
\end{abstract}

Keywords: Yugoslavia, repression, dictatorship of King Aleksandar, Communist Party, early socialism, political opponents.

$\mathrm{D}$ uring the $19^{\text {th }}$ and early $20^{\text {th }}$ century political life in Serbia was marked with persecution, expulsion and public humiliation of arrested political opponents, electoral violence and ferocious partisan squabbles. The partial militarization of society, as the result of wars and the growing influence of the secret military organization Black Hand, adversely affected fragile democratic traditions. Although the creation of a multinational Kingdom of Serbs, Croats and Slovenes was the embodiment of a modern state idea, continuous inter-ethnic conflicts, as well as activities of far-right organizations (Ustaša, VMRO), prevented and hindered democratization.

Different aspirations of (national) political elites were manifested immediately after unification. Despite the persistence of most Croats and Slovenes on their own ethnic particularities, the idea of one nation with three different names ('troimeni narod') was taken as a starting point for further integration and coexistence within the newly formed state. Supporters of centralism and unitarianism, mainly the members of Serbian political elite, wanted to erase all ethnic peculiarities and create a single nation. On the other hand, members of other national elites (especially Croats) believed that such an "administrative" model of nation building represents a serious threat to their national individualities and

\footnotetext{
* The paper is part of the project Serbian Society in the Yugoslav State in the 20 $0^{\text {th }}$ Century: Between Democracy and Dictatorship (no. 177016) funded by the Ministry of Education, Science and Technological Development of Republic Serbia.
} 
specificities. ${ }^{1}$ Constant ethnic squabbling along with the difficult economic conditions and widespread poverty became a catalyst for a permanent and profound state crisis that prevented any legislative work. Unprepared for compromises on the federalist ground, the king and the ruling political elite believed that oppressive measures against the political opponents would enable a rapid internal cohesion. ${ }^{2}$ Unresolved long term problems brought the country to a standstill. Accumulated inter-ethnic conflicts and divisions reached a boiling point during the Second World War. Great human and material losses, a polarized society and the disappearance of the old political system were some of the consequences of war. After the liberation, the revolution continued. By promising a better life and assuring the masses that the "old shall never return,"3 party leaders tried to consolidate power, neutralize political opponents and achieve sustainable reconciliation in a country where national conflicts had resulted in terrible war atrocities.

Milton Fisk points out, "without the state's ability to use force to deal with offenders it is unlikely that the state rule could be consolidated". Moreover, the crimes that are perceived as a threat to the society as a whole are punishable in each state. "Repression then works with state justice to reinforce the state's power to rule". ${ }^{4}$ Juridical protection of the state often includes offenses against the reputation of the state, its highest representatives, as well as lower officials, its insignia (flag, emblem, anthem), as well as some offenses against public security. Armed insurrection, terrorism, political assassinations are considered as crimes that are punishable in each country. However, the legitimate right of a state to self-defense cannot be misused for the elimination of human rights and freedoms. ${ }^{5}$

State repression reached its peak during the dictatorship of King Aleksandar (19291935) and in the period of early socialism (1945-1953). Weak democratic traditions and the predominant notion that opponents of the regime are enemies of the state were some of the factors that paved the way for state repression. Rigid legislation, political trials, surveillance and persecution of political opponents, full scale control of the citizens, the instrumentalisation of schools and teachers for the purpose of ideological upbringing, infringing on the independence of the judiciary, censorship, suspicion towards foreigners and encouragement of citizens to demonstrate their loyalty to the regime by denouncing their neighbors and acquaintances were some of the main repressive mechanisms and matrices which, with a greater or lesser intensity, were continuously implemented during the seven decades of the Yugoslav state.

\section{Dictatorship of King Aleksandar (6 January 1929 - 5 May 1935)}

During the summer of 1928 King Aleksandar faced a difficult constitutional, parliamentary and state crisis to which political parties did not have an answer. As the attempts of resolving the crisis by political and parliamentary means failed, the king turned

\footnotetext{
${ }^{1}$ See Stanković 1995: 85 - 86, 93 - 96; Matković 1999: 84 - 85; Dimić 2001: 56 - 63; Čalić 2013: 106 - 108; Petranović, Zečević: 120 - 121;

${ }^{2}$ Petrović 2009: 40 - 41.

${ }^{3}$ Tito 1959: 176.

${ }^{4}$ Fisk 1998: 97

${ }^{5}$ Bavcon 1987: 83 - 86, 98, 94.
} 
the country towards the dictatorship. In the early morning of 6 January 1929, on the Orthodox Christmas Eve, the monarch addressed his subjects informing them about the change of the regime and explaining the motives that provoked him to take such a step. In the manifesto entitled "To my dear people, to all Serbs, Croats and Slovenes" the king emphasized that the parliamentary system "was abused by the political parties to the to the extent that it had become an impediment for every fruitful work in the country....Instead of developing and strengthening the spirit of national and state unity, parliamentarism, such as it is, is beginning to lead to spiritual disintegration and to national division”. Thus, the king dissolved the National Assembly and abolished the Vidovdan constitution. ${ }^{6}$

The newly established regime was supposed to be temporal. In an interview given to a French journalist the king explained that he was compelled to take such a step in order to save the country from the brink of anarchy. ${ }^{7}$ The reasons which drove King Aleksandar to resolve a profound political crisis in such a radical manner were numerous. The parliamentary system in the Kingdom of Serbs, Croats and Slovenes was severely compromised during the late twenties. Political parties were interested only in gaining and remaining in power. Parties were national by character and thus paid attention only to the interests and needs of their own nation, often neglecting and ignoring the interests of the state as a whole. Political rhetoric consisted of inflammatory language and demagogic slogans which were misused on the daily basis. Populism and cheap nationalism were most clearly visible in slogans and "argumentation" that insisted on Serbian hegemony and clash of the Western civilization with the (inferior) Byzant culture. On the other hand, Serbian political elite stubbornly insisted on a centralized state and national unity, thus denying political, cultural and historical particularities. In such an atmosphere, governmental and parliamentary work was almost completely halted. ${ }^{8}$ During the period 1918-1929, 25 governments were changed. In such circumstances many advocated for the inauguration of a government that would be run by a high ranking military official and even for transition to the dictatorship. ${ }^{9}$ The National Assembly became the scene of fierce verbal and sometimes physical confrontations that culminated in June 1928. In the assassination that took place in the Assembly two MPs were killed and three wounded, including Stjepan Radić, who later died. ${ }^{10}$

The suspension of the Constitution, the ban of political parties, the Law on Royal power and High State Administration, the Law on the Protection of Public Security and Order in the State, the Law on State Court for the Protection of the State, the amended Law on the Press and newly inaugurated ideology of integral Yugoslavism gave the legislative foundation for state repression. According to the Law on the Protection of Public Security and Order in the State, all political parties and all associations that bore "tribal" and "religious" name were banned and were supposed to dissolve themselves immediately. New

\footnotetext{
${ }^{6}$ Proklamacija „Mome dragom narodu, svim Srbima, Hrvatima i Slovencima“, Službene novine Kraljevine Srba, Hrvata i Slovenaca, 6. 1. 1929.

7 “Da bi sačuvao jedinstvo i budućnost svoje Kraljevine”; Politika, 17. 1. 1929.

${ }^{8}$ Dobrivojević 2006: 38 - 43.

9 Šarac 1969: 55 - 59; Gligorijević 1979: 251 - 252.

${ }^{10}$ Gligorijević 2002: $306-308$.
} 
societies could be formed only with the special permit of authorities. ${ }^{11}$ By the administrative decision of the police, all those who "disturbed" public order could be expelled from their place of residence to any other place. According to the law, persons who were once expelled could return only if veliki župan allowed them to do so. Anyone who would dare to return without the permit of the authorities would be punished with 30 days of imprisonment and deported again. ${ }^{12}$ Thus, the Law on the Protection of Public Security and Order in the State actually legitimized voluntary expulsions without the court order. Moreover, although the Constitution (1931) ${ }^{13}$ and the Criminal Code (1929) ${ }^{14}$ strictly prohibited internments without a court order, such interments to remote, underdeveloped and isolated towns and villages, usually situated in Bosnia and Sandžak, became one of the main methods of controlling political opponents - leaders and members of banned political parties who were labeled as the enemies of the regime. "Tutin was the smallest district place in the country of which I have never heard" wrote Dragoljub Jovanović about his internment in $1933 .{ }^{15}$ Besides Jovanović, other leading political figures were interned. For defying the king Svetozar Pribićević was sent to Brus (1929), Vlatko Maček to Čajniče, Većeslav Vidler to Bijelo Polje and Anton Korošec to Vrnjačka Banja and latter Hvar. Among the internees were also Vjekoslav Kulovec (Foča), Marko Natlačen (Bileća), Anton Ogrizek (Ključ), and Duda Bošković (Novi Pazar). In order to demonstrate its firmness, the regime tried to humiliate some of the political opponents. Although ill-thought actions of oppression were numerous, the most reckless were taking shackled Maček into custody (1929) or chaining university professor Dragoljub Jovanović together with a criminal and transporting him to Kragujevac (1932). In the long run, it turned out that such a conduct of the authorities came with the cumulative negative effect. The escalation of the oppression was provoking open resentment and revolt in domestic and international public and creating an overwhelmingly negative image not only of the regime, but of the country as well. Moreover, political opponents of the regime knew how to turn political adversities into an advantage - leaders of the opposition were well aware that such abuses and brutal violation of their rights were actually contributing to the creation of the image of heroes. Dragoljub Jovanović later wrote in his memoirs that the members of the opposition believed that it was "desirable" to be imprisoned, because it was the easiest way of collecting most effective political points and wining over the sympathy of the masses. ${ }^{16}$ However, putting aside the fact that interments represented the loss of personal freedoms, internees were housed in the homes of the wealthiest people in the area, well fed and relatively well informed about events in the country. ${ }^{17}$

\footnotetext{
${ }^{11}$ Zakon o zaštiti javne bezbednosti i poretka u državi, Službene novine Kraljevine Srba, Hrvata i Slovenaca, 6. 1. 1929.

12 Zakon o zaštiti javne bezbednosti i poretka u državi, Službene novine Kraljevine Srba, Hrvata i Slovenaca, 6. 1. 1929.

${ }^{13}$ Ustav Kraljevine Jugoslavije, Službene novine Kraljevine Jugoslavije, 3. 9. 1931.

14 V. Čubinski 1934.

${ }^{15}$ Jovanović 1997 vol III: 69.

${ }^{16}$ Ibid, v II, 256.

${ }^{17}$ Political memories 1997 v III : 27, 80, 163; AJ, 135 - 69 - 4 / 32; Vidler's letter to a friend (1931); AJ, 37 11 - 71; Milan Stojadinović’s letter to Branko Peleš (29. 3. 1933). V. Dobrivojević 2006: 228 - 235.
} 
The newly established State Court for the Protection of the State became the highest court in the country that played a crucial role in suppressing the opponents of the regime. In the case of conviction, there was no legal remedy to the declared verdict. The rigidness of the legislation was clearly visible in the fact that members of Ustaša and VMRO, politicians of the banned parties, university professors, communists, spies, petty violators and all those accused of spreading alarming news were suspected for offences against public security and order in the state and summoned to court. Although many defendants were sentenced to long-term imprisonments, compared to the number of reports that were coming to the office of the State Prosecutor, the number of cases brought before the State Court for the Protection of the State the was relatively small. For example, during 1929 chief district officials filed around 2300 reports to the State Prosecutor's Office. Paradoxically, even some petty offences were regarded as criminal acts punishable by the Law on the Protection of Public Security and Order in the state. ${ }^{18}$ Such zealous behavior of the local officials speaks volumes about their ignorance of legal procedures and overall incompetence.

Until 1932 the majority of the prosecuted before the State Court for the Protection of the State were the members of the Communist Party. However, due to the numerous terrorist attacks - the assassinations of prominent political and public figures (Toni Šlegel, Andrija Berić, the attempt of assassination of King Aleksandar), bomb detonations in international trains, railroads and in downtown Belgrade, the Velebit uprising, members of Ustaša and VRMO organization became the most frequently prosecuted perpetrators. However, only a few politicians were prosecuted before the State Court for the Protection of the State. Both Maček and Jovanović were acquitted during the first trial. The authorities were informed about the plans of Košutić and Krnjević, prominent members of the Croatian Peasant Party, to illegally go to exile, but they did nothing to stop them. After the first trial Maček was issued a passport for the alleged medical treatment in Czechoslovakia. Moreover, depending on circumstances and the overall situation in the country, authorities sometimes knew to turn a blind eye on law violations committed by the opposition. On the eve on November elections (1931) the police found many forbidden books, brochures and leaflets in Maček's apartment, but he was never summoned to court. ${ }^{19}$

Although political opponents and all prominent figures unsympathetic to the regime were put under strict, full-time surveillance, very little effort was put into building modern and well-organized police and repressive apparatus. Croatian politicians Vlatko Maček, ${ }^{20}$ Ivan Pernar, ${ }^{21}$ Juraj Krnjević, Josip Predavec, Avgust Košutić, Svetozar Pribićević, ${ }^{22}$ Većeslav Vidler, Milan Šuflaj and Ante Trumbić ${ }^{23}$ and Serbian politicians Ljuba Davidović, Jovan Jovanović, Dragoljub Jovanović, Milan Grol, Miloš Trifunović, ${ }^{24}$ Milan Gavrilović,

\footnotetext{
${ }^{18}$ V. Archive of Yugoslavia (in further text AJ) 135 - 1 - 42.

${ }^{19}$ Dobrivojević 2006: 255 - 256.

${ }^{20}$ Maček 1957: 126.

${ }^{21}$ AJ, 135 - 81 - 43 / 32, D. S. br. 43 / 932.

22 Maček 1957: 126.

${ }^{23}$ Janjatović 2002: 263.

${ }^{24}$ AJ, $37-9-48$.
} 
Duda Bošković ${ }^{25}$ and Milan Kostić ${ }^{26}$ were among the surveilled. Under special scrutiny were the people living in bordering areas. Any visits to the border zone were perceived as suspicious. Thus, in Croatia, 50 police agents had to monitor the trains that were traveling from and to the border stations. In addition, 12 more agents were ordered to observe carefully the travelers at the main railway station in Zagreb. ${ }^{27}$ The techniques of surveillance were primitive as authorities did not try to develop more sophisticated methods of control or to build a modern repressive apparatus. Moreover, police agents were sometimes unskillful and clumsy. Ante Pavelić, the leader of the Ustaša organization, fled the country although one agent followed him and monitored his house until there was light in the apartment. $^{28}$

As in the parliamentary period, political elites were not able to draw a line between the state and the regime. Thus, it was believed that loyalty to regime equals loyalty to the state. The passive stance was unacceptable since "all those who are not politically active" were perceived as the opposition to the regime. ${ }^{29}$ Therefore, the authorities tried to control not only the actions of political opponents, but to suppress all opposing notions against the newly established regime. Friendly or family ties with all those labeled as the enemies of the regime provoked the deepest suspicion. All those who were considered to be "troublemakers" and "spiritual leaders and initiators of political disorder" were preventively detained during the national holidays and other important dates. ${ }^{30}$ As the new ideology of integral Yugoslavism was to become a cohesive element in a polarized society, civil servants were put under special pressure. The lack of a modern and efficient administrative apparatus along with the prevailing notion that the purpose of the bureaucracy was to serve the regime created an atmosphere in which civil servants were expected to be the main supporters of the new ideology. In such an atmosphere civil servants, heavily dependent on the political (and personal) will of the governing elite, even during the parliamentary period, had to endure surveillance and often faced vague and poorly substantiated charges such as "not sufficiently involved in the agitation in favor of the regime.”31

Although legislation and the explicit orders of state authorities forbade any excessive use of force, the lack of modern gendarmerie and police apparatus along with a perplexing domestic situation contributed to the frequent abuse of authority and excessive use of force. Members of the police and gendarmerie apparatus often treated suspects as already convicted violators, denying the right to defend themselves and to hire a lawyer. ${ }^{32}$ Complaints about tortures and physical abuse by the police were often heard on trials, especially before the State Court for Protection of the State. Some of the defendants gave detailed statements about the maltreatment to which they were exposed, while others accused police of intimidation and the extortion of confession by beating. Although officials

\footnotetext{
${ }^{25}$ AJ, $14-21-48$.

${ }^{26}$ AJ, $74-11-22$.

${ }^{27}$ Nielsen 2002: 358.

${ }^{28}$ Krizman 1983: 53 - 54 .

${ }^{29}$ Dimić 1994: 189.

${ }^{30} 27^{\text {th }}$ regular meeting of the National Assembly, shorthand notes 1934: 482.

${ }^{31}$ Dobrivojević $2006: 118$.

${ }^{32}$ V. Dobrivojević 2006 : 175 - 176.
} 
usually investigated all accusations against the police - mistreatment of detainees, denial of the right to counsel and excessive use of force, these investigations usually stopped even before they really began. Misconduct of policemen and gendarmes could never be proven because of the strong solidarity among the members of the gendarmerie. Not realizing that misconduct and brutality of gendarmes and policemen was intensifying the already complex inter-ethnic and inter-religious relations, authorities rarely decided to dismiss gendarmes. Moreover, the transfers occurred rarely, since it was believed that gendarmes would be more successful in performing duties if they were well acquainted with the area they were working in. ${ }^{33}$ This protective attitude of the authorities additionally contributed to the feeling of indisputable authority and power among some members of gendarmerie and police forces. The authorities were particularly vulnerable to the frequent criticism of the police and gendarmerie in the Assembly. Numerous interpellations dedicated to the misconduct of the gendarmerie were ignored. Moreover, the authorities thought that such discussions were harmful for the image of the state. Given the perplexing security situation, the political elite believed that excessive brutality was permitted and perhaps even desirable. $^{34}$

Through strict police surveillance and control, politically motivated trials, internal exiles and forbiddance of any activity that was in collision with the proclaimed political course regime attempted to suppress all opposition. However, the already existing methods of control, dating from the parliamentary period, were improved. The surveillance of civil servants, pressures and abuses during the elections, extorting confessions by torture and criminal prosecution for insulting the king and the royal family were part of the practice that was inherited from the previous parliamentary period. Nevertheless, the regime never tried to organize an efficient repressive apparatus. The only exception was the establishment of Central Press Bureau - the organization that scrutinized and censored the press, giving precise instructions to journalists regarding the tone and style in which articles were supposed to be written. Political opponents were surveilled, arrested and trialed. However, relatively tolerable conditions in prisons enabled them to freely propagate their political beliefs and send propaganda materials and pamphlets from penitentiaries. Civil servants were often monitored and denounced to the authorities, but almost never dismissed from the state service.

\section{Revolution takes its toll. Early Socialism in Yugoslavia (1945-1953)}

From the autumn of 1944, while the war was still going on, the Party began to square accounts with all those who were perceived as quislings or political and ideological enemies. Terrible atrocities committed in the civil war, along with the fact that the fighting for liberation continued until mid May 1945, created an atmosphere in which a spiral of violence gained its momentum. In October 1944 a high party official Koča Popović stated: "Justice involves revenge, justice includes revenge." 35 During the liberation of the new

\footnotetext{
${ }^{33}$ Transfer of gendarmes, Policija, 17 - 18 / 1929, 808.

34 AJ, 63 - 18 / 1934, Pov. br 28 863, 18. 7. 1934; Dobrivojević 2006: 192 - 193.

${ }^{35}$ Cvetković $2006: 235$.
} 
territories, partisans "purged" all those who collaborated or supported puppet governments that were installed on occupied territories. Marie-Janine Čalić writes that "OZNA executed all those who were in its reach". An American liaison officer stationed in Dubrovnik wrote: "Partisans believe that anyone who lived in the city during the occupation and did not participate in the resistant movement is a collaborator. Everyone is afraid of the secret police that takes people out of their homes and shoots them on daily basis." 36

Although many European countries (France in particular) were swept by a wave of executions, public humiliations, assaults and detentions of suspected collaborators immediately after the war, the scope of repression seen in early socialist Yugoslavia was vaster. After the liberation, the revolution continued. Under the guise of modernization and cultural progress, Yugoslav agrarian society was being reshaped in accordance with the Party's programmed. Thus, it was acceptable to use 'forceful means' in order to prevent 'all those who wanted to hinder the construction of socialism'. ${ }^{37}$ Repressive measures against opponents of the revolution were not brought to an end. Legislative activity, primarily the Law on the Offences against the People and the State, ${ }^{38}$ the Law on Confiscation, ${ }^{39}$ the Law on Agrarian Reform and Colonization ${ }^{40}$ and the Law on Nationalization of private companies $^{41}$ facilitated repression and enabled the institutionalization of violence. The Department for the Protection of People (OZNA) and later the State Security Department (UDBA) became the main organ of the repression. Intimidation, threats, physical violence and unjustified arrests were the most frequently used methods of the police in fight against all those who were considered to be opponents of the regime. Officers of UDBA believed that they were "above the government and above the law". They easily accused people and took them to custody for minor offenses. ${ }^{42}$ According to the Prosecutor's Office and the Ministry of Internal Affairs, $47 \%$ of the arrested were released after the investigation. ${ }^{43}$ Edvard Kardelj, one of the leaders of the Party, argued that reckless arrests created the atmosphere in which no one was ashamed for being imprisoned. "Jail thus became a part of everyday life", stated Kardelj, "such as the flu or an injury." 44

The judiciary apparatus, whose independence was compromised in the pre-war period, became a tool in the hands of authorities. It was believed that the courts and judges "have to contribute as much as possible to the strengthening and development of the achievements of the people's revolution, socialist construction and the people's government". ${ }^{45}$ Some of the judges were appointed on the merits of war, regardless of their qualifications. In these circumstances, "people's committees, public prosecutors and local party authorities sought to subordinate the court and turn it to their executive organ". ${ }^{46}$ Before the court judgment,

\footnotetext{
36 Čalić 2013: 214.

${ }^{37}$ Dobrivojević 2014: $81-82$.

${ }^{38}$ Zakon o krivičnim delima protiv naroda i države, Službeni list DFJ, 1. 9. 1945.

${ }^{39}$ Zakon o konfiskaciji, Službeni list DFJ, 12. 6. 1945.

40 Zakon o agrarnoj reformi i kolonizaciji, Službeni list DFJ, 28. 8. 1945.

${ }^{41}$ Zakon o nacionalizaciji privatnih privrednih preduzeća, Službeni list DFJ, 6. 12. 1946.

42 Petranović, Končar, Radonjić 1985: 522.

${ }^{43}$ Ibid, 522 - 523.

${ }^{44}$ Ibid, 567.

${ }^{45}$ Ibid, 511.

${ }^{46}$ Ibid, 526.
} 
verdicts that were to be declared in the major trials were discussed in the Politburo. Similarly, federal and local authorities were considering "less important" penalties. ${ }^{47}$ Because of the loyalty to the regime or the overall incompetence, many judges believed that the Public Prosecutor's Office should be consulted before sentencing the penalty. ${ }^{48}$ After the promulgation of the new, less restrictive Criminal Code in 1951, the judicial system remained under the control of the Party, but the pressures and forms of control become milder and more sophisticated. ${ }^{49}$

Until the summer of 1945, all persons who were suspected of being war criminals and "enemies of the people" were tried on basis of the Decree of Supreme Headquarters regarding the Military Courts. A shortened procedure, a confession as the major proof of guilt, draconian penalties and the inability to appeal to the verdict represented some of the main characteristics of the trials before military courts. ${ }^{50}$ According to the Law on Crimes against the People and the State (August 1945) punishable were all acts that aimed to threaten the "state order" and "basic democratic, political, ethnic and economic achievements of the liberation war - federated state, brotherhood and equality of nations and people's government." 51 Vaguely defined crimes enabled the government to easily neutralize all those who were perceived as political opponents. Slobodan Jovanović, Konstantin Fotić, Radoje Knežević and Milan Gavrilović were tried in absence (1946) as the members of Yugoslav war cabinet in exile. In 1947 the prewar politicians Dragoljub Jovanović, Toma Jančiković and Franc Snoj, who joined the People's Front after the liberation, were charged for trying "to create a peasant block as a united anti-communist opposition.”" Ac According to Đilas, Tito himself ordered the arrest of Dragoljub Jovanović, because of his speech on cooperatives held in the Assembly (summer 1946). When Aleksandar Ranković noticed that it would be difficult to find anything on Jovanović, Tito laconically replied: "If he is not guilty, fabricate charges against him". "Until that moment", Đilas later wrote in his memoires, "we used to amplify culpability. However, some culpability, at least according to our ideological and revolutionary criteria, existed. And now the culpability was supposed to be fabricated."53

The conflict with the Soviet Union brought about the further demise of personal freedoms and tightening of the repressive measures. In order to prove its own ideological purity and devotes to the communist ideology, the Party accelerated a campaign for the establishment of cooperatives. At the same time, the persecution against all party members and sympathizers who opted for Stalin started. Thus, according to the data cited by Srđan Cveković, around 50,000 people were arrested and around 30,000 penalized. Federal and republic ministers, members of the Parliament, generals and even the members of the Politburo were among the arrested. In order to isolate the pro-Stalinist opposition within the Party, Yugoslav communist leadership decided to establish Goli otok - the first camp for

\footnotetext{
47 Đilas 1983: 37.

${ }^{48}$ Petranović, Končar, Radonjić 1985: 552.

${ }^{49}$ Cvetković 2006: 159.

${ }^{50}$ Cvetković 2011: 169.

${ }^{51}$ Zakon o krivičnim delima protiv naroda i države, Službeni list DFJ, 1. 9. 1945.

52 Cvetković 2006: 336 - 342.

53 Đilas 1983: 36.
} 
Cominform supporters (1949). The police authorities were given the right to impose "administrative penalties", i.e. to assess the seriousness of the offense and to decide on the length of the educational-correctional measure (imprisonment). Although the administrative penalty was supposed to be only "preventive and temporary isolation", prisoners were deprived of all fundamental rights. In some cases even the families were not told where their kins were taken. Torture was one and only method of "re-education" and the prisoners were expected to divulge all the supporters of the USSR they knew. ${ }^{54}$ Although the camp on Goli otok was closed in 1958, closer ties with the Western countries, relative liberalization and democratization of the system as well as the cessation of military threat, resulted in a partial relaxation of torture and reducing the number of prisoners. ${ }^{55}$

Although the Constitution (1946) formally guaranteed the right to private property, the regime was willing to tolerate individual entrepreneurship only as long as it was necessary. Members of the pre-war elite were gradually deprived of their properties - through expropriation, confiscation, nationalization and land reform. Persecuted and politically defeated members of the pre-war bourgeoisie did not have the strength to stand up to the new policy. Thus, by the end of 1946, 83\% of industrial enterprises ended up in the hands of state. ${ }^{56}$ The British Embassy in Belgrade reported that despite the relatively moderate law on confiscation of war gains (May 1945), the aim of prosecuting war profiteers was mainly of political nature. Confiscations, as a mandatory part of the judgment, represented merely a tool for the implementation of an important segment of the government's economic policy - nationalization of private property. ${ }^{57}$ Private property was not given much recognition. In the post-war atmosphere in which all means were allowed in order to carry out the revolution, the spiral of economic violence was gaining its momentum. In a fierce newspaper campaign citizens were encouraged to report on their "over-wealthy" neighbors. People were deprived of their assets even without a formal trial. ${ }^{58}$ In "absurd" trials, ${ }^{59}$ verdicts for war profiteering were declared "without sufficient evidence or without serious arguments - based on the belief that someone lived luxuriously before the war and now has a wealthy lifestyle". ${ }^{60}$ Aware of the possible political consequences that these forms of lawlessness could provoke, Party officials reacted. The Central Committee of the Serbian Communist Party issued the following directive: "Trials of war profiteers are especially important from a political and economic point of view. Such trials should be helped but we should vigorously fight against aberrations."61

Parallel with the isolation of all those who were perceived as the enemies of the revolution, the transformation of the Yugoslav agrarian society continued. Under the guise of modernization, an unrealistic economic policy was accepted. For the sake of building a

\footnotetext{
${ }^{54}$ Cvetković, 2011: 55 - 58.

${ }^{55}$ Cvetković, 2006: 381.

${ }^{56}$ Ribić, 1989: 121.

57 Jarman 1997: 569 - 570.

58 Jarman 1997: 582

59 Jarman 1997: 667.

${ }^{60}$ AS, Đ 2 - IV - 1; Minutes of the counselling with secretaries and members of the county committee held on 18 and 19 March 1949.

${ }^{61}$ Dobrivojević, 2013: 73 - 74.
} 
bright socialist future, Yugoslav citizens were forced to be reconciled to the poverty surrounding them. Everyone was expected to take an active part in the rebuilding of the society - peasants had to produce the required quantities of food, workers had to work, students to study. ${ }^{62}$ Since rapid industrialization was accompanied by a chronic labor shortage, local Party authorities, afraid of reprimands in case of failing to meet the compulsory plan quotas, used coercion in order to mobilize workers. Peasants, youth, and even school teachers were among the mobilized. ${ }^{63}$ Economic pressures, intimidations, interrogations, ${ }^{64}$ arrests and beatings ${ }^{65}$ were some of the repressive measures used across Yugoslavia. Although the Party generally condemned repressive measures, the perpetrators of the oppression were never punished. On the other hand, local authorities were continuously intimidated and threatened that they would be scrutinized, criticized and openly exposed in the press. District officials thus represented the scapegoats who were supposed to accept all the responsibility for any failure of the plan. With the first signs of liberalization of the regime in 1950, such practice was abandoned for good. Tito openly acknowledged that in Istria the youth "taken by force" was jumping out of trucks "breaking legs and heads" in order to escape. ${ }^{66}$

Over-ambitious investments and haste for industrialization in a poor and underdeveloped agrarian country could be funded solely by the relocation of financial means from agriculture. In the first months after the liberation it was possible to find various economic and social justifications for the introduction of forced deliveries of agricultural products. Later it turned out that requisitions represented merely a political instrument by which farmers were forced to deliver their product in exchange for the symbolic compensation. Requisition campaigns resembled "punitive expeditions" 67 in which the grain was seized with extreme brutality. The situation worsened in 1947 when, in accordance with the new method of procurement, peasants were given delivery quotas in advanced - before sowing and before anyone could assess the expected yield. ${ }^{68}$ Quantities of products, especially of grain, that were to be handed out were rising constantly. Passive resistance to grain seizure became widespread and peasants tried to protest by writing appeals to the officials. ${ }^{69}$ However, the government and the judicial authorities did not have much understanding for peasants' assurances that they were not able to deliver the required quantities. Faced with the refusal to hand the grain over, local officials established improvised prisons throughout villages. Peasants were "arrested, beaten, and often sadistically tortured." Those who resisted grain seizure were "tied to plum trees, forced to stand in the cold water, forced to live in the premises full of smoke, spitted on, humiliated, starved and taken to mock executions.” Arrests were that widespread that no one, including the Prosecution office, had any insight into how many people passed through prisons.

\footnotetext{
62 Dobrivojević, 2013: 103.

${ }^{63}$ V. Dobrivojević 2009: 141 - 154

${ }^{64}$ Pov br 49 / 50 (27.1. 1950), AJ, 25 - 154 - 407.

${ }^{65}$ Shortcomings of including workforce in August (20.9.1949); AJ, 25 - 154 - 407.

${ }^{66}$ Petranović, Končar, Radonjić 1985: 410.

${ }^{67} \mathrm{AV}, 334$ - 1043; Shorthand notes from different sessions in the CC of the CPS and PC of the CPS in 1947.

${ }^{68}$ AJ, 40 - 98 - 227; Report on the system and state of supply in the FNRY.

69 A JBT, KMJ, II - 5-a - 1 / 19; Implementing the party line in villages.
} 
Officials in charge with force deliveries "often lost sense of proportion and exaggerated in the arrests.” Thus, imprisonments became a part of everyday life. Many farmers came to the hearings prepared for jail, carrying along "blankets, bread and brandy.” Indifferent towards any punishment, they refused to discuss delivery quotas and just asked "in which basement to go."70

The abandonment of rigid dogmatic views and the Soviet state model, the economy in shambles and financial and military support from Western countries led to the loosening of Party discipline, gradual reforms and noticeable liberalization of the system. Declarative advocacy of "democratization" reached its peak during the Fourth plenum of the Central Committee (June 1951). In their speeches, Party leaders condemned repressive measures and different forms of violence practiced in the period 1945-1950. Edvard Kardelj publicly stated: "We have been supporters of gross political violence so far, but now we made complete U-turn in law". In the period 1952-1953, during the closest cooperation with the West, relative democratization was continued. A rigid administrative management of the economy was abandoned, a new planning and financial system adopted, forced deliveries abandoned and most of the cooperatives disbanded. Although the death of Stalin and a new shift in foreign policy temporary slowed the democratization and liberalization of the Yugoslav society, a large scale oppression and gross persecutions were abandoned for good. ${ }^{71}$

\section{An Attempt of Comparison}

The state repression during the royal dictatorship and the one in the early socialist Yugoslavia cannot be compared in their scope, extent and brutality. The regime of King Aleksandar was authoritarian and in many ways similar to the dictatorships established in some European and particularly Balkan countries (Poland, Greece). The king and the ruling political elite stubbornly resisted the necessary and inevitable constitutional changes on the federalist grounds. Dictatorship was thus seen as the only type of reign that could preserve the centralistic state organization. Therefore, the ideology of integral Yugoslavism was supposed to bring about the consolidation of the domestic situation and contribute to the calming of inter-ethnic conflicts. On the other hand, the brutal civil war, the revolutionary transformation of society, squaring the accounts with political opponents, the dogmatic rigidness of Party leadership, a complete and uncritical adoption of the Stalinist state model, the split with the USSR and the constant feeling of military threat (first from the West and later from the East) were some of the main reasons why the regime established in the early socialist years was totalitarian.

Besides all the differences that substantially shaped state oppression in the interwar and postwar periods, some similarities exist. A deeply divided society, fear of the "internal enemy" (members of the far right and communists in the inter-war period, defeated bourgeoisie in early socialism), bad relations with the neighboring countries and an inflammatory situation on borders created an atmosphere in which fear became one of the

\footnotetext{
${ }^{70}$ Dobrivojević 2013: 333 - 334 .

${ }^{71}$ Ibid, 154.
} 
catalysts of excessive use of force. Not only people, but also the low ranking officials were affected by this spiral of oppression. Threatened with reprimands, fines or loss of service if they would reluctantly perform their duties, low instances were particularly zealous in the prosecution of real and fictitious political opponents. Despite the declarative commitment to legality, both regimes did nothing to stop police brutality and violence. Informal protection of the state, together with arrogance and a sense of power, created the atmosphere in which many members of the police apparatus believed that they were above any law. The primitive conception of justice must have significantly contributed to the brutality, since many believed that the appropriate penalty should be more severe than the offense committed. ${ }^{72}$ Both regimes introduced surveillance of people as the methods of control. Insulting the king, a member of the royal family (in the inter-war period) or Tito and highranking members of the communist elite (in early socialism) was regarded as a serious violation and thus punishable by imprisonment. In both regimes, the authorities could learn of such offenses only with the help of the local population. Many citizens, either out of a sense of duty or in pursuit for special benefits, were willing to voluntarily cooperate with the regime and provide it with the information on "suspicious" acquaintances and neighbors. Such benevolent "cooperation" speaks volumes about the mentality of people and the relationship to the government that, in some way, enabled the onset and duration of undemocratic regimes.

Due to the weak democratic traditions, ruling elites believed that loyalty to the regime equals loyalty to the state. A passive stance was unacceptable since all citizens were expected to actively support the regime and advocate the existing ideology. Thus, both regimes were facilitating a further polarization of the society, easily labeling all nonsympathizers as state enemies. The notion that the bureaucratic apparatus should be in service of the regime and insistence on political "suitability" enabled strict scrutiny of civil servants who were expected to zealously profess the political conception of the government. The instrumentalisation of education and the ideological upbringing in schools, interference with the judiciary and a dismissal and retirement of all those who were perceived as politically and ideologically inappropriate for state service were all part of the arsenal both regimes were employing.

Although the repressive matrix was similar in many ways, the frequency and intensity of repression were more formidable in early socialism. Harassment, intimidation, illtreatment, arbitrary arrests, fabricated charges, unfair trials and various economic pressures were more frequent than in the inter-war period. The right to custodia honesta that was granted to political prisoners in the inter-war period was abolished after the war. Since the role of the perpetrator and the victim were inverted, communist leaders used their "experience" from jails in order to create a prison system in which all communication between political prisoners would be disabled. ${ }^{73}$ Censorship became more severe, every critical opinion was suppressed and the scale of self-censorship was constantly growing out of fear of persecution. The right to the private property was almost non-existent during the first post-war years. Confiscations, expropriation and nationalization were some of the

\footnotetext{
72 Dobrivojević 2006: 159.

${ }^{73}$ Milovan Đilas, Vlast (London: Naša reč, 1983), 9.
} 
measures that enabled the government to get a hold of all vital economic assets. Moreover, through the campaign against "speculators", "bourgeoisie" and "kulaks" the communist regime was turning citizens against each other, as authorities were calling people to report all "excessively" rich neighbors and those who had "surplus" housing. Civil rights were grossly violated on a daily basis as the authorities had the right to mobilize workforce and to expel so called "unproductive" citizens from Belgrade and other larger cities.

Although the liberalization in the early 1950s led to a reduction in the intensity of repression and to the adoption of more sophisticated methods of surveillance and control, social stigma with which "enemies of the people" had to live persisted for years and sometimes even decades. Former prisoners were regarded with distrust and suspicion and faced insurmountable challenges in career advancement. ${ }^{74}$ Thus, they were never fully reintegrated in the society.

\section{REFERENCES:}

Unpublished primary sources:

Archive of Yugoslavia

Centralni Pressbiro

Državni sud za zaštitu države

Dvor

Fond Ministarstva unutrašnjih poslova

Kominterna - Sekcija KPJ

Ministarstvo pravde

Ministarstvo rada FNRJ

Privredni savet

Zbirka Milana Stojadinovića

Archive of Serbia

Centralni komitet Saveza komunista Srbije

Published primary sources:

Jarman, R. Yugoslavia. Political Diaries 1918 - 1965, v III, London: Slough: Archive Editions, 1997.

Peti kongres Komunističke partije Jugoslavije 21 - 28. jula 1948. Stenografske beleške, Belgrade: Kultura, 1948. (Serbian Cyrillics)

Petranović, B, Končar R, Radonjić R. Sednice Centralnog komiteta KPJ : 1948 - 1952, Belgrade: Komunist, 1985.

Stenografske beleške Narodne skupštine, Belgrade: Štamparija Vladete S. Janićijevića, 1934.

Tito, J. B. Govori i članci, v VI, Zagreb: Napred, 1959.

Periodicals:

Policija

Politika

Službene novine Kraljevine Srba, Hrvata i Slovenaca,

Službeni list DFJ

\footnotetext{
${ }^{74}$ Srđan Cvetković, Izmedju srpa i čekića. Represija u Srbiji 1944 - 1953 (Belgrade: Insitut za savremenu istoriju, 2006), 293.
} 
References:

Bavcon, Lj. Kaznenopravna zaštita države i njenog društvenog uređenja, Zagreb: Globus, 1987.

Cvetković, S. Izmedju srpa i čekića. Represija u Srbiji 1944 - 1953, Beograd: Insitut za savremenu istoriju, 2006.

. Izmedju srpa i čekića 2. Politička represija u Srbiji 1953 - 1985, Beograd: Insitut za savremenu istoriju, 2011.

Čalić, M. Ž. Istorija Jugoslavije, Beograd: Clio, 2013. (Serbian Cyrillics)

Čubinski, M. Naučni i praktični komentar krivičnog zakonika Kraljevine Jugoslavije, Beograd: Geca Kon, 1934. (Serbian Cyrillics)

Dimić, Lj, "Država, integralno jugoslovenstvo i kultura“, Književnost, 1 - 2 - 3, 1994, 171 - 2017. (Serbian Cyrillics)

. Istorija srpske državnosti. Srbija u Jugoslaviji, Novi Sad: SANU 2001. (Serbian Cyrillics)

Dobrivojević, I. "Privatnost pod nadzorom. Ograničavanje ličnih sloboda u Kraljevini Jugoslaviji 1929 - 1935“, Historijska traganja, 2, 2008, 117 - 142.

"Urbanization in Socialism. Everyday life in Yugoslav Towns 1945-1955“, in: Katrina Gulliver, Helena Toth (eds.), Cityscapes in History. Creating the Urban Experience, London: Ashgate, 2014, 81 - 98.

. Državna represija u doba diktature kralja Aleksandra 1929 - 1935, Beograd: Insitut za savremenu istoriju, 2006.

. Selo i grad. Transformacija agrarnog društva Srbije: 1945 - 1955, Beograd: Insitut za savremnu istoriju, 2013.

. "Jedan dokument o položaju prosvetnih radnika u Federativnoj Narodnoj Republici Jugoslaviji“, Arhiv, 1, 2009, 141 - 154

Đilas, M. Vlast, London: Naša reč, 1983.

Fisk, M. The State and Justice: An Essay in Political Theory, Cambridge: Cambridge University Press, 1989.

Gligorijević, B. Kralj Aleksandar Karadjordjević. Srpsko - hrvatski spor, Beograd: Zavod za udžbenike, 2002. (Serbian Cyrillics)

. Parlament i političke stranke u Jugoslaviji 1918 - 1929, Beograd: Institut za savremenu istoriju, 1979.

Janjatović, B. Politički terror u Hrvatskoj: 1918 - 1935, Zagreb: Hrvatski insitut za povijest, 2002.

Jovanović, D. Političke uspomene, v II - III, Beograd: Arhiv Jugosloslavije, 1997. (Serbian Cyrillics)

Maček, V. In the Struggle for Freedom, New York: Robert Speller \& Sons, 1957.

Matković, H. Povijest Hrvatske seljačke stranke, Zagreb: Naklada PIP Pavličić, 1999.

Krizman, B. Ante Pavelić i ustaše, Zagreb: Globus, 1983.

Nielsen, C. "One State, One Nation, One King. The Dictatorship of King Alexandar and His Yugoslav Project 1929 - 1935“. PhD thesis, Columbia University, 2002.

Petranović, B, Zečević, M. Agonija dve Jugoslavije, Šabac: Zaslon, 1991.

Petrović, Lj. Jugoslovensko medjuratno društvo u mreži vlasti, Belgrade: Insitut za savremenu istoriju, 2009

Ribić, V, "Koncepcija prvobitne socijalističke akumulacije u Jugoslaviji (razdoblje četrdesetih i pedesetih godina - 1945 - 1954)”, Časopis za suvremenu povijest, 1 - 3, 1989. 105 - 128.

Stanović, Đ. Nikola Pašić i Hrvati, Beograd: BIGZ, 1995. (Serbian Cyrillics)

Šarac, N. Uspostavljanje šestojanuarskog režima sa posebnim osvrtom na Bosnu i Hercegovinu, Sarajevo: Svjetlost, 1975. 


\title{
IVANA DOBRIVOJEVIĆ \\ Institut za savremenu istoriju, Beograd \\ ŽIVOT POD DIKTATUROM. REPRESIVNE PRAKSE U JUGOSLAVIJI
}

\begin{abstract}
Rezime
Odusustvo istinske demokratije i veće ili manje ograničavanje političkih i ličnih sloboda obeležili su svih sedamdeset godina postojanja Jugoslavije. Politički progoni, instumentalizovanje pravosuđa, nasilje žandarmerije i policije, nadozor nad svim političkim neistomišljenicima, gušenje slobode pisane reči i brutalna cenzura predstavljaju samo neke od karakteristika represije u periodu 1929-1935 i 1945-1953. Ipak, iako su represivne matrice za kojima se posezalo u doba šestojanuarske diktatutre i u prvoj posleratnoj deceniji veoma slične, obim i brutalnost represije teško su uporedivi. Autoritarni režim kralja Aleksandra je ličio na diktature uspostavljene u nekim evropskim i posebno balkanskim državama (npr. Poljska, Grčka).

Nespreman za dogovor sa političkim protivnicima koji su zagovarali preuređenje države na federalističkoj osnovi, kralj je posegao za diktaturom ne bi li konsolidovao političke prilike i ublažio međunacionalne tenzije. I dok je želja za očuvanjem postojećeg političkog poretka predstavljala jedan od glavnih motiva za pooštravanja represije u prvoj polovini tridesetih godina prošlog veka, želja za revolucinonarnom transformacijom društva u skladu sa maksimom „staro ne sme nikad više da se vrati“ i nekrično kopiranje sovjetskog modela umnogome je uticalo na brutalni karakter represije u prvim posleratnim godinama. Zastrašivanja, hapšenja i maltretiranja onih koji su smatrani političkim protivnicima, politički motivisana suđenja i ekonomski pritisci su bili daleko učestaliji u ranom socijalizmu nego u vreme šestojanuarske diktature. Pravo na custodiu honestu je ukinuto, a partijski funkcioneri su svoje iskustvo boravka u kaznenim zavodima u Kraljevini Jugoslaviji iskoristili da naprave Centralni zatvor za politčke krivce u kome bi zatvorenicima bilo onemogućeno da međusobno ilegalno komuniciraju. Kampanja protiv „špekulanata“, „,narodnih neprijatelja“ i „kulaka“ je, naročito u prvim mesecima posle oslobođenja, poprimala obrise javnog linča, a građani su pozivani da prijavljuju svoje imućne komšije i sve one koji su imali višak stambenog prostora. Rasprostranjeno shvatanje da su neprijatelji režima zapravo i državni neprijatelji davalo je, i u međuratnom i u posleratnom periodu, zamajac represiji i podsticalo veliki broj građana da, bilo iz osećanja dužnosti ili iz želje za kakvom korišću, dobrovoljno sarađuju sa vlastima.

Ključne reči: Jugoslavija, represija, diktatura kralja Aleksandra, komunistička partija, rani socijalizam, politički protivnici.

(C) Faculty of Philosophy, Novi Sad, 2016

ISTRAŽIVANJA - JOURNAL OF HISTORICAL RESEARCHES 27, 225-240
\end{abstract}

